\title{
Enzyme electrophoresis method in analysis of active components of haemostasis system
}

\author{
Ludmila Ostapchenko, Oleksiy Savchuk, Nataliia Burlova-Vasilieva
}

Educational and Scientific Centre "Institute of Biology" of National Taras Shevchenko University of Kyiv, Kyiv, Ukraine. Email: burlova@mail.ru

Received 9 December 2010; revised 16 January 2011; accepted 20 January 2011

\begin{abstract}
The novel modifications of substrate-containing sodium dodecyl sulfate-polyacrylamide gel electrophoresis that can be used for the detection of proteases and its activators are reported. The protease/activator samples were separated on a protein substrateSDS-polyacrylamide gel. To detect plasminogen activators fibrinogen and Glu-plasminogen were incorporated into the SDS-PAG followed by $1 \mathrm{~h}$ incubation at $37^{\circ} \mathrm{C}$ in thrombin solution $(1 \mathrm{NIH} / \mathrm{ml})$. After electrophoresis the gel was stained according to the standard protocol. To detect fibrin-unspecific plasminogen activators from snake venom incubation in thrombin solution was substituted for $12 \mathrm{~h}$ incubation in $50 \mathrm{mM}$ Tris-HCl (pH 7.4). To detect fibrinogendegrading enzymes fibrinogen-containing gel was used. Activity of protease/activator was visualized in the gel as clear bands against the dark background. These new techniques offer several advantages including determination of the quantity and activity of t-PA and urokinase, however cannot be recommended for precise quantification of activators; the total procedure is quite quick and simple; method is convenient tool for detection of novel protein-protein interactions in haemostasis system; the sensitivity of the method is $\leq \mathbf{0 . 0 1} \mathrm{IU}$ per track.
\end{abstract}

Keywords: Substrate-Containing Electrophoresis; Enzyme Electrophoresis; Haemostasis; Proteins Activity; Proteins Identification

\section{INTRODUCTION}

Protein electrophoresis is a convenient approach to characterize sample composition, protein interactions, purity, molecular weight, isoelectric point, and to purify small amounts of protein for further analysis. Different modifications of this widely used method have been developed to suit a variety of purposes [1].

Erickson [2] and Brunner [3] offered fibrin autogra- phy to detect protease activators/inhibitors previously fractionated by sodium dodecyl sulfate polyacrylamide gel electrophoresis (SDS-PAGE). After separation the proteins and the substrate were transferred electrophoretically into the fibrin indicator gel. The positions of activators/inhibitors were revealed by the formation of contrast fibrinolytic or lysis-resistant zones.

Hanspal et al. [4] described a technique to detect the activity of protease inhibitors present in enzyme substrate-containing sodium dodecyl sulfate polyacrylamide gel (SDS-PAG). The method involved 1) incorporation of substrate (gelatin or casein) into the SDS-PAG at the time of casting; 2) electrophoresis of the protease inhibitors in the presence of SDS; 3) removal of SDS by washing the gel in $2.5 \%(\mathrm{w} / \mathrm{v})$ Triton X-100; 4) incubation of the gels in a solution containing the proteolytic enzyme at 37 degrees $\mathrm{C}$ for $16 \mathrm{~h}$; and 5) staining undigested substrate with amido black.

Sensitive methods for detecting proteases/protease inhibitors by using fluorescent protease substrates in gels are reported [5,6]. Wilkesman and Schroder [7] used 2-D zymography, a technique that combines IEF (isoelectric focusing) and zymography. Procedures including highmolecular-mass substrates within the gel, such as starch for identification of amylase activity, and protein substrates, such as gelatin, casein, and collagen, for revealing protease/protease inhibitors activity, have been described [8-10].

There are several features of enzyme activity determination including protection of protein functional activity. This provides the possibility of enzyme identification after all biochemical manipulations. Although, it is not possible to save $100 \%$ of functional activity, however most of researchers succeeded to save nativity of the protein (including its activity) at the level which is sufficient authentic and adequate identification.

In the present study we report 1D SDS-PAG enzyme electrophoresis method. The technique is optimized for identification of proteases/protease activators of haemostasis system in the blood plasma or other tissue samples. 
The major advantage of the method is the possibility to detect active plasminogen activators - tissue-type plasminogen activator (t-PA) and urokinase which simplifies analytical work [11-13]. Enzyme electrophoresis can be used as a rapid diagnostic method as gives information not only about the amount and MW of proteins but also reveals active forms of t-PA and urokinase.

Fibrinogen or (fibrinogen and plasminogen) was incorporated into the gel as a substrate for proteases. The convertion of fibrinogen to fibrin under thrombin treatment provides conditions for fibrin-dependent activators to generate plasmin causing the background substrate degradation [14].

\section{MATERIALS AND METHODS}

Chemicals and proteins. Tris, glycine, SDS, acrylamide, bisacrylamide, ammonium persulfate (APS), N,N,N',N'tetramethylethylenediamine (TEMED), sucrose, all of analytical grade, were purchased from Amersham Biosciences $\mathrm{AB}$ (Sweden). t-PA, urokinase and elastase were obtained from Sigma, Germany. Streptokinase was supplied by Kabi Pharmacia AG, Sweden.

Sample preparation. Mouse blood plasma from Lewis carcinoma line C57B1/6 was received from Kavetskiy Institute of experimental pathology, oncology and radiobiology of the National Academy of Siences of Ukraine.

Subretinal fluid isolated by surgical operation from patients with regmatogenic retina exfoliation was received from Filatov Institute of eye diseases and tissue therapy of the Academy of Medical Sciences of Ukraine.

The crystalline snake venom of Agkistrodon halys halys was received from serpentarium of Tripolskiy biochemical plant, Ukraine.

All samples were mixed with treatment buffer in the ratio $1: 1(\mathrm{v} / \mathrm{v})$ and stored before electrophoresis at $4^{\circ} \mathrm{C}$. The treatment buffer was made ready according to Amersham Biosciences protocol [15] with modifications: 1) glycerine was replaced by sucrose to the final concentration 5\% and 2) DTT was not added to prevent the loss of enzyme activity. The obligatory condition for enzyme electrophoresis samples preparation was nonthermal treatment of the samples before separation to avoid the loss of enzyme activity.

\section{ENZYME ELECTROPHORESIS}

We have developed a technique on the basis of the method described by Heusen C. and Dowdle E., [16] with following modifications: fibrinogen $(1 \mathrm{mg} / \mathrm{mL})$ or (fibrinogen $(1 \mathrm{mg} / \mathrm{mL})$ and Glu-plasminogen $(10 \mathrm{mkg} /$ $\mathrm{mL}$ ) was incorporated into separating PAG. Fibrinogen was used to detect proteases capable of fibrinogen cleavage (in this study plasminogen and mini plasminogen, see Example 4, Figures 4(a) and 5). Fibrinogen and plasminogen were incorporated into SDS-PAG for plasminogen activators detection. After separation the gel was incubated in thrombin solution $(1 \mathrm{NIH} / \mathrm{mL})$ for 1 $\mathrm{h}$ at $37^{\circ} \mathrm{C}$. Fibrin formation was required for development of the fibrin-dependent plasminogen activators $(\mathrm{t}-$ PA and urokinase) activity [17]. t-PA or urokinase appeared as the clear bands, corresponding to the area where plasmin has degraded fibrin. The separation gel concentration can vary from $11 \%$ to $15 \%$ to prevent migration of incorporated proteins during electrophoresis.

The technique involved: 1) incorporation of fibrinogen or (fibrinogen and plasminogen) into the SDS-PAG of required concentration; 2) electrophoretic separation under usual conditions [15]; 3) gel washing in $2.5 \%$ Triton X-100 with shaking for $1 \mathrm{~h}$ at $25^{\circ} \mathrm{C}$ for SDS removal; 4) for (fibrinogen and plasminogen)-incorporated gel -treatment with thrombin solution with shaking for $1 \mathrm{~h}$ at $\left.37^{\circ} \mathrm{C} ; 5\right)$ proteins visualization according to standard protocol [15].

For electoforesis performing and gel staining procedures Hoefer Mighty Small system and Hoefer Processor Plus (Amersham Biosciences AB, Sweden) were used.

The sensitivity of the method was $\leq 0.01$ IU of activator or protease per track.

\section{WESTERN BLOTTING}

Procedure was performed according to the protocol [17]. Proteins were transferred to a nitrocellulose membrane for $1 \mathrm{~h}$ at $4^{\circ} \mathrm{C}$ and $60 \mathrm{MA}$ in $15 \mathrm{mM}$ Tris- $\mathrm{HCl}, \mathrm{pH} 8.4$ with $120 \mathrm{mM}$ glycine and $20 \%$ methanol. The membrane was stained with $0.1 \%$ Ponso "Sigma" in 5\% acetic acid with shaking for 30 min followed by overnight incubation in $5 \% \mathrm{BSA}$ at $4^{\circ} \mathrm{C}$. Proteins were probed using monoclonal antibody (MAb) directed against plasminogen (Merck KGaA, Germany) in dilution 1:1000 and secondary antibody (1:3000) labeled with alkaline phosphatase. Each procedure was followed by rinsing step with 3 buffer substitutions. The washing buffer consisted of $50 \mathrm{mM}$ Tris- $\mathrm{HCl}$ with $0.1 \%$ Twin-20. The blot was developed using 5-bromo-4-chloro-3indolyl phosphate.

\section{PROTEINS PURIFICATION}

Human Glu-plasminogen was purified from citrateanticoagulated blood plasma by affinity chromatography on Lys-Sepharose [18]. The citrate-anticoagulated blood plasma was diluted 1:1 with $50 \mathrm{mM}$ sodium-phosphate, pH 7.4 containing aprotinin (1000 IU/L), filtered and loaded onto Lys-Sepharose column previously equilibrated in the same buffer lacking aprotinin. After loading the column was washed with $50 \mathrm{mM}$ sodium-phosphate, pH 7.4 with $200 \mathrm{mM} \mathrm{NaCl}$, and eluted with $150 \mathrm{mM}$ 6-aminohexacapronic acid in the same buffer. By adding 
ammonium sulfate $(41 \mathrm{mg} / \mathrm{ml})$, crude plasminogen was precipitated from the eluate and gel-filtrated using Sephacryl S-200 column. Purified plasminogen was stored frozen at $-20^{\circ} \mathrm{C}$ until used.

Activation of plasminogen was performed on a column loaded with insolubilized urokinase. [19]. Gluplasminogen was incubated within the column for $1 \mathrm{~h}$ at $37^{\circ} \mathrm{C}$ in $50 \mathrm{mM}$ Tris- $\mathrm{HCl}$, pH 7.4 with $150 \mathrm{mM} \mathrm{NaCl}$ and $25 \%$ glycerol. The purity of plasmin was controlled by SDS-PAGE and found to be homogenous. The protein was stored frozen at $-20^{\circ} \mathrm{C}$ in $50 \%$ glycerol.

Mini-plasmin was obtained according to the method described by March, Parikh and Cuatrecasas [20]. Gluplasminogen $(10 \mathrm{mg}$ per $1 \mathrm{ml}$ ) was hydrolyzed with pancreas elastase 1:50 (v/v) in $50 \mathrm{mM}$ Tris- $\mathrm{HCl}, \mathrm{pH} 8.5$ with $100 \mathrm{mM} \mathrm{NaCl}$ for $5 \mathrm{~h}$ at $25^{\circ} \mathrm{C}$. The reaction was stopped by adding of pNFGB to final concentration 10 $\mathrm{mM}$. The hydrolyzate was loaded onto Superdex 75 for mini-plasminogen separation from cryngls 4 and 1-3. The purified mini-plasminogen was lyophilized and stored at $-20^{\circ} \mathrm{C}$. The purity of mini-plasminogen was controlled by SDS-PAGE and found to be homogenous.

\section{RESULTS AND DISCUSSION}

Human, rabbit, bovine, porcine and mouse haemostasis proteases/protease activators were visualized through this method. To provide optimal results fibrinogen and plasminogen of target mammal should be used for incorporation. However, authors examined usage of human plasminogen and fibrinogen as a background substrate for haemostasis proteases of mammalian species listed above. This significantly simplifies the analysis [21-25].

Advantages and possibilities of enzyme-electrophoresis method are shown in four different cases. In the present study authors did not bring out data of alternative techniques of haemostasis system analysis. Previous reports have confirmed results obtained by enzymeelectrophoresis, references to original studies are indicated in the text and included to the list.

Example 1: The increased risk of acute myocardial infarction (AMI) is associated with reduced fibrinolytic activity. Increased levels of thrombin-antithrombin III complex, fibrinopeptide A, prothrombin fragment $\mathrm{F} 1+2$ and D-dimer are detectable in patients affected by thrombosis. [26-30]. The level of t-PA antigen is increased but associated with decreased t-PA activity [31-33].

For patients who had AMI, we documented an increased fibrinolytic potential after streptokinase $(\mathrm{Sk})$ administration [21]. To determine the reason of plasmin formation we used rabbit and porcine models of thrombolytic therapy. Whereas Sk activates human and rabbit plasminogen, it fails to activate porcine. This allowed us to distinguish plasmin and Sk effects. The total plasminogen activators were determined using enzymeelectrophoresis. (Figures 1(a), (b)). PAG was prepared in the presence of both fibrinogen and Glu-plasminogen. After separation the gel was treated with thrombin. Activity of plasminogen activators was visualized as bands cleared from fibrin by the activated proenzyme included to the gel.

Figure 1(a) demonstrates that rabbit blood plasma contains proteins with fibrinolytic activity and molecular weights of 82,70 and $54 \mathrm{kDa}$, which correspond to plasmin, t-PA and two-chain urokinase-type plasminogen activator (tcu-PA). Increment of plasmin and t-PA activities was visible 1 hour after streptokinase administration. Porcine plasma contained the same proteins, but $54 \mathrm{kDa}$ band was barely visible indicating the trace amount of tcu-PA in the sample (Figure 1(b)). t-PA activity was significantly increased 1 hour after thrombolytic agent administration. This indicates that t-PA activity is associated with Sk independently of plasmin formation.

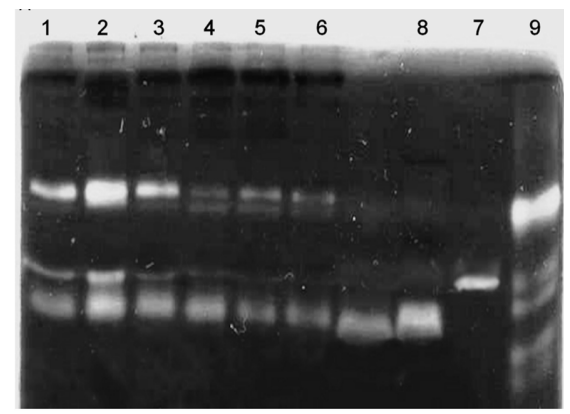

(a)

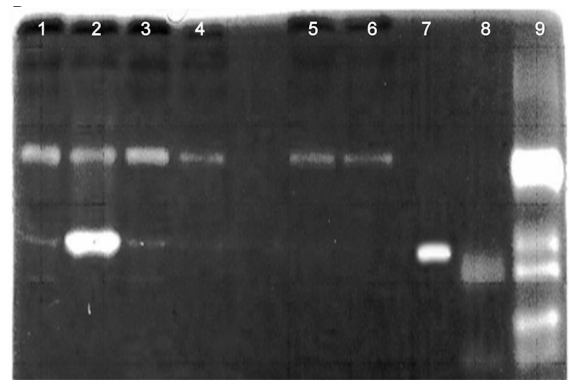

(b)

Figure 1. Enzyme electrophoregram of rabbit (a) and porcine (b) blood plasma: 1) control (before streptokinase administration); 2) $1 \mathrm{~h}$ after streptokinase administration; 3) $4 \mathrm{~h}$ after streptokinase administration; 4) 1 day after streptokinase administration; 5) 3 days after streptokinase administration; 6) 7 days after streptokinase administration; 7) t-PA standard (MW 70 $\mathrm{kDa}$ ); 8) urokinase standard (MW 56, $33 \mathrm{kDa}$ ); 9) plasmin standard (MW $82 \mathrm{kDa}$ ). 
Example 2: Snake venoms are complex mixtures containing many different biologically active proteins and peptides. A number of these proteins affect the blood coagulation pathway, endothelial cells, and platelets [34]. Several venom enzymes have been used as anticoagulants and other are under examination of their possible therapeutic potential. We used enzymeelectrophoresis to detect potential plasminogen activator in Agkistrodon halys halys venom. For this purpose fibrinogen and plasminogen were incorporated into the PAGE. The mixture of previously purified activator and plasminogen 1:1 (q/q) was used as a sample. The gel was not treated with thrombin but after SDS on Triton $\mathrm{X}-100$ substitution was incubated for 12 hours in $50 \mathrm{mM}$ Tris-HCl, $\mathrm{pH} 7.4$ for development of plasmin activity due to action of potential activator. In the analyzed sample (Figure 2) two bands were found. One of them corresponded to $82 \mathrm{kDa}$ plasmin, which had been formed under activator action. The second band corresponded to MW of activator itself ( $32 \mathrm{kDa})$, its appearance was provided by plasminogen incorporation. These results suggest that induction of plasmin formation by the snake venom activator was specific and involved a bond cleavage at a specific site in the plasminogen molecule without formation of active fragments.

These results were completely confirmed using specific chromogenic substrate for plasmin [22].

Example 3: To detect components of plasminogen activation system in the subretinal fluid of patients with regmatogenic retina exfoliation enzyme-electrophoresis was performed. This substance is accumulated in the

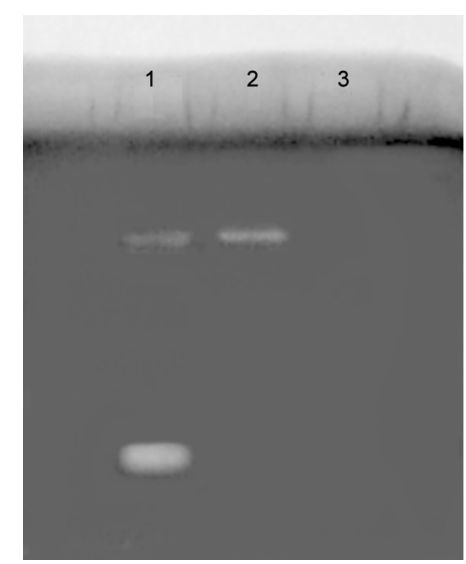

Figure 2. Enzyme electrophoregram of plasminogen and plasminogen activator from snake venom mixture: 1) plasminogen and plasminogen activator mixture; 2) plasmin standard (MW $82 \mathrm{kDa}$ ); 3) plasminogen standard used for incubation and incorporation. cavity formed by pathologic retina exfoliation. It was shown that subretinal fluid possessed fibrinolytic activity and included an activator capable of plasminogen trans formation. To determine the nature of this activator (or activators) fibrinogen and plasminogen-incorporated gel was used. After separation and SDS removal the gel was incubated in thrombin for fibrin formation. This step was necessary due to fibrin-dependent nature of t-PA and urokinase activities. The $54 \mathrm{kDa}$ band was revealed at the electrophoregram (Figure 3(a)) and confirmed the existence of tcu-PA in the sample.

Previous reports have confirmed results obtained by substrate-incorporated electrophoresis [23,35].

Example 4: Production of elastase is significantly enhanced in tumor cells leading to formation of plasminogen internal fragments (angiostatine that consists of kringles 1 to 4 and approximately $85 \%$ of kringle 5) [3639]. Unbound plasminogen/plasmin cringles are biologically active molecules that act on distant sites affecting fibrinolytic efficiency [39-42].

Using enzyme-electrophoresis method we analyzed proteases and plasminogen activators composition in the blood plasma of Lewis carcinoma mice (Figure 4(a)). The analysis of haemostasis system during Lewis carcinoma growth is reflected in the study [24].

Fibrinogen and Glu-plasminogen were incorporated into the PAG. After separation of the samples and SDS removal the gel was incubated in thrombin solution for fibrinogen transformation. Appearance of active bands revealed plasminogen activators and proteases capable of fibrin cleavage. As migration pattern of the size (Mr) standards elastase $(27,29$ and $31 \mathrm{kDa})$, urokinase (33 and $56 \mathrm{kDa})$, tPA $(70 \mathrm{kDa})$ and mini-plasmin $(36 \mathrm{kDa})$ were used. The resulting electropherogram for this case

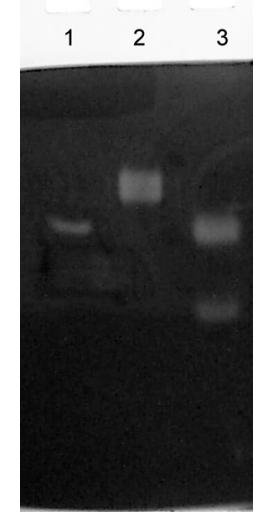

Figure 3. Enzyme electrophoregram of subretinal fluid: 1) subretinal fluid; 2) t-PA standard (MW $70 \mathrm{kDa}$ ); 3) urokinase standard (MW 56, $33 \mathrm{kDa}$ ). 


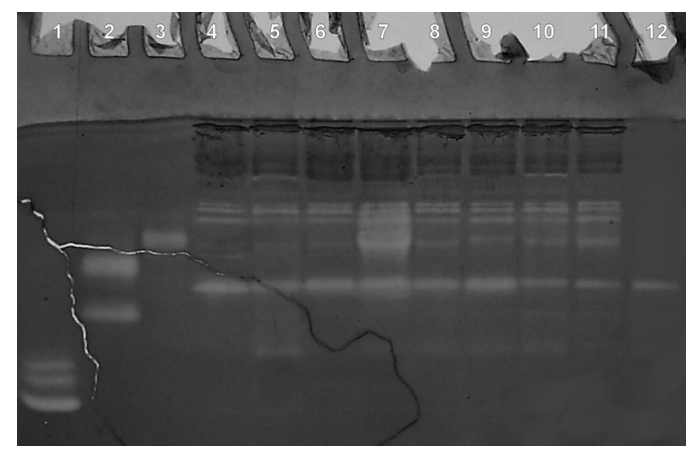

(a)

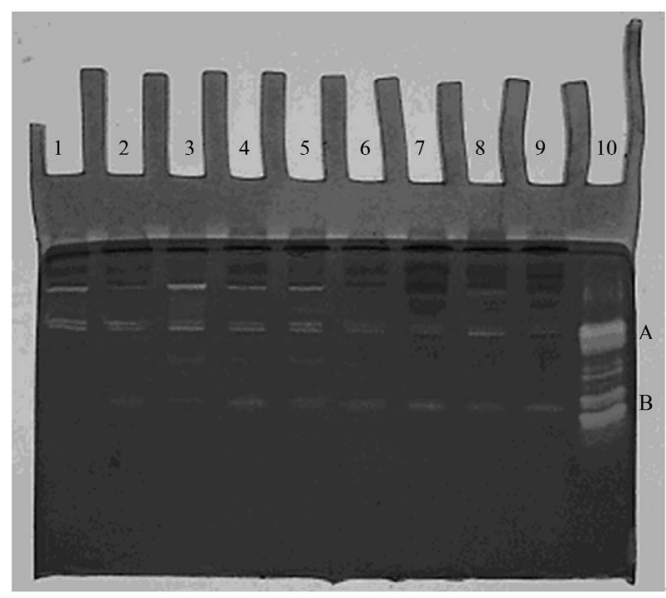

(b)

Figure 4. (a) Enzyme electrophoregram of plasminogen activators and active proteases from Lewis carcinoma mice blood plasma: 1) elastase standard (MW 31, 29, 27 $\mathrm{kDa}$ ); 2) urokinase standard (MW 56, $33 \mathrm{kDa}$ ); 3) t-PA standard (MW $70 \mathrm{kDa}$ ); 4-11) blood plasma samples; 12) miniplasmin standard (MW $36 \mathrm{kDa}$ ); (b) A Enzyme electrophoregram of active proteases capable of fibrinogen cleavage from Lewis carcinoma mice blood plasma: 1) control blood plasma; 2-9) Lewis carcinoma mice blood plasma samples; 10) standards: A-plasmin (MW $82 \mathrm{kDa}$ ), B-miniplasmin (MW $36 \mathrm{kDa}$ ).

is shown on the Figure 4. All samples displayed an active zones with MW of $31 \mathrm{kDa}$, which corresponded to elastase, $36 \mathrm{kDa}$ (mini-plasmin), $70 \mathrm{kDa}$ (t-PA) and 33 $\mathrm{kDa}$ (urokinase). Some samples contained high molecular weigh urokinase (band with MW of $56 \mathrm{kDa}$ ).

In order to detect active proteases capable of fibrinogen cleavage, incorporation of plasminogen and fibrinogen into fibrin transformation steps were excluded. This analysis of Lewis carcinoma mice blood plasma revealed active zones with MW corresponding to plasmin (82 $\mathrm{kDa})$ and mini-plasmin $(36 \mathrm{kDa})$. To confirm our results western-blot with MAb directed against plasminogen [43] was performed (Figure 5). Data obtained by western blotting testified that enzyme electrophoresis could be used for plasmin and mini-plasmin detection.

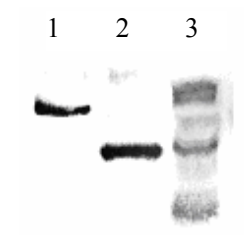

Figure 5. Western-blot of Lewis carcinoma mice blood plasma with MAb directed against plasminogen: 1) plasmin standard (MW 82 $\mathrm{kDa}$ ); 2) miniplasmin standard (MW $36 \mathrm{kDa}$ ); 3) blood plasma sample.

\section{CONCLUDING REMARKS}

Our findings indicate that enzyme-electrophoresis method shows reliable results for identification of active t-PA and urokinase. The technique can be used for studying of protease composition and protein-protein interactions in haemostasis system. The total procedure is quite quick and simple and can be recommended as alternative medical diagnostic method used for the rapid assessment of plasma fybrinolytic potencial.

\section{REFERENCES}

[1] Westermeeier, R. and Naven, T. (2002) Proteomics in practice: A laboratory manual of proteome analysis, Wiley-VCH Verlag GmbH.

[2] Erickson, L., Lawrence, D. and Loskutoff, D. (1984) Reverse fibrin autography: A method to detect and partially characterize protease inhibitors after sodium dodecyl sulfate - polyacrylamide gel electrophoresis. Analytical Biochemistry, 137, 454-463. doi:10.1016/0003-2697(84)90113-1

[3] Brunner, G. and Schirrmacher, V. (1988) Fibrin autography of plasminogen activator by electrophoretic transfer into fibrin agar gels. Analytical Biochemistry, 168, 411-416. doi:10.1016/0003-2697(88)90337-5

[4] Hanspal, J., Bushell, G. and Ghosh, P. (1983) Detection of protease inhibitors using substrate-containing sodium dodecyl sulfate-polyacrylamide gel electrophoresis. Analytical Biochemistry, 132, 288-293. doi:10.1016/0003-2697(83)90010-6

[5] Zhao, Z. and Russell, P. (2003) Trypsin activity assay in substrate-specific one- and two-dimensional gels: A powerful method to separate and characterize novel proteases in active form in biological samples. Electrophoresis, 24, 3284-3288. doi:10.1002/elps.200305531

[6] Le, Q., Ohashi, A., Hirose, S. and Katunuma, N. (2005) Reverse zymography using fluorogenic substrates for 
protease inhibitor detection. Electrophoresis, 26, 10381045. doi:10.1002/elps.200306142

[7] Wilkesman, J. and Schroder, H. (2007) Analysis of serine proteases from marine sponges by 2-D zymography. Electrophoresis, 28, 429-436. doi:10.1002/elps.200600332

[8] Le, Q. and Katunuma, N. (2004) Detection of protease inhibitors by a reverse zymography method, performed in a tris(hydroxymethyl)aminomethane-Tricine buffer system. Analytical Biochemistry, 324, 237-240. doi:10.1016/j.ab.2003.09.033

[9] Martinez, M., Newbold, C., Wallace, R. and Movano, F. (2002) Effects of high-molecular-mass substrates on protein migration during sodium dodecyl sulfatepolyacrylamide gel electrophoresis. Electrophoresis, 23, 1-7.

[10] Vazquez, D. and Peyronel, A.C. (1995) A simple and rapid technique for postelectrophoretic detection of proteases using azocasein. Electrophoresis, 16, 1894-1897.

[11] Fareed, J., Hoppensteadt, D. and Leya, F. (1998) Useful laboratory tests for studying thrombogenesis in acute cardiac syndromes. Clinical Chemistry, 44, 1845-1853.

[12] Zawilska, K. (1995) Progress in the detection of intravascular activation of fibrinolysis. Acta haematologica polonica, 26, 33-38.

[13] Bu, C., Zhang, C. and Li, Z. (2007) Autoantibodies to plasminogen and tissue plasminogen activator in women with recurrent pregnancy loss. Clinical \& Experimental Immunology, 149, 31-39. doi:10.1111/j.1365-2249.2007.03382.x

[14] Hoylaerts, M., Rijken, D., Lijnen, H. and Collen, D. (1982) Kinetics of the activation of plasminogen by human tissue plasminogen activator. Role of fibrin. Journal of Biological Chemistry, 257, 2912-2919.

[15] Protein Electrophoresis. (1999) Technical manual, Amersham Biosciences Inc.

[16] Heussen, C. and Dowdle, E. (1980) Electrophoretic analysis of plasminogen activators in polyacrylamide gels containing sodium dodecyl sulfate and copolymerized substrates. Analytical Biochemistry, 102, 196-202. doi:10.1016/0003-2697(80)90338-3

[17] Harlow, E. and Lane, D. (1988) Antibodies. Cold Spring Harbor Laboratory, New York.

[18] Chibber, B., Deutsch, D. and Mertz, E. (1974) Affinity chromatography of plasminogen. Methods in Enzymology, 34, 424-432.

[19] Wiman, B. and Wallen, P. (1973) Activation of human plasminogen by an insoluble derivative of urokinase. Structural changes of plasminogen in the course of activation to plasmin and demonstration of a possible intermediate compound. European Journal of Biochemistry, 36, 25-31. doi:10.1111/j.1432-1033.1973.tb02880.x

[20] March, S., Parikh, I. and Cuatrecasas, P. (1974) A simplified method for cyanogen bromide activation of agarose for affinity chromatography. Analytical Biochemistry, 60 , 149-152. doi:10.1016/0003-2697(74)90139-0

[21] Krasnobryzha, E., Savchuk, O. and Volkov, G. (2004) Study of streptokinase influence on the haemostasis system parameters in model systems in vivo. Ukrainian Biochemical Journal, 76, 56-61.

[22] Savchuk, O., Levkin, M., Karbovskyy, V., Gornitskaya, O., Volkov, G. and Tseren, B. (2006) Plasminogen acti- vatof from Agkistrodon halys halys venom. Ukrainian Biochemical Journal, 78, 32-37.

[23] Platonova, T., Gornitskaya, O., Metelitsina, I. and Savchuk, O. (2001) Components of blood clotting system and fibrinolytic system in subretinal fluid at regmatogenic retina exfoliation. Medichna Chimia, 3, 5-8.

[24] Petik, A., Platonova, T. and Savchuk, O. (2001) Indexes of haemostasis system during Lewis carcinoma growth. Experimental Oncology, 23, 73-75.

[25] Zhukova, A., Krasnobrysha, I. Savchuk, O. and Volkov, G. (2009) The investigation of protein-protein interactions in haemostasis system using enzyme electrophoresis method. XXII Congress of the International Society of Thrombosis and Haemostasis. Journal of Thrombosis and Haemostasis, 7, Boston, USA, 367.

[26] Bruhn, H., Conard, J., Mannucci, M., Monteagudo, J., Pelzer, H., Reverter, J., Samama, M., Tripodi, A. and Wagner, C. (1992) Multicentric evaluation of a new assay for prothrombin fragment $\mathrm{F} 1+2$ determination. Thromb Haemost, 68, 413-417.

[27] Ferlito, S., Gallina, M., Mangiameli, S. and Chiaranda, G. (1995) Thrombotic markers during myocardial infarctionPanminerva. Panminerva Medica, 37, 133-136.

[28] Granger, C., Becker, R., Tracy, R., Califf, R., Topol, E., Pieper, K., Ross, A., Roth, S., Lambrew, C. and Bovill, E. (1998) Thrombin generation, inhibition and clinical outcomes in patients with acute myocardial infarction treated with thrombolytic therapy and heparin: Results from the GUSTO-I Trial. GUSTO-I Hemostasis Substudy Group. Global Utilization of Streptokinase and TPA for Occluded Coronary Arteries. Journal of the American College of Cardiology, 31, 497-505. doi:10.1016/S0735-1097(97)00539-1

[29] Johns, J., Gold, H., Leinbach, R., Yasuda, T., Gimple, L., Werner, W., Finkelstein, D., Newell, J., Ziskind, A. and Collen, D. (1988) Prevention of coronary artery reocclusion and reduction in late coronary artery stenosis after thrombolytic therapy in patients with acute myocardial infarction. A randomized study of maintenance infusion of recombinant human tissue-type plasminogen activator Circulation, 78, 546-556.

[30] Nilsen, D., Goransson, L., Larsen, A., Hetland, O. and Kierulf, P. (1997) Systemic thrombin generation and activity resistant to low molecular weight heparin administered prior to streptokinase in patients with acute myocardial infarction. Tromb Haemost, 77, 57-61.

[31] Chandler, W. and Stratton, J. (1994) Laboratory evaluation of fibrinolysis in patients with a history of myocardial infarction. American Journal of Clinical Pathology, 102, 248-252.

[32] Genser, N., Lechleitner, P., Maier, J., Dienstl, F., Artner-Dworzak, E., Puschendorf, B. and Mair, J. (1998) Rebound increase of plasminogen activator inhibitor type I after cessation of thrombolytic treatment for acute myocardial infarction is independent of type of plasminogen activator used. Clinical Chemistry, 44, 209-214.

[33] Yamada, S., Yamada, R., Ishii, A., Ashikawa, K., Kawamitsu, H. and Fujita, K. (1996) Evaluation of tissue plasminogen activator and plasminogen activator inhibitor-I levels in acute myocardial infarction. Journal of Cardiology, 27, 171-178. 
[34] Markland, F. (1998) Snake venoms and the hemostatic system. Toxicon, 36, 1749-1800. doi:10.1016/S0041-0101(98)00126-3

[35] Immonen, I., Konttinen, Y., Sorsa, T., Tommila, P. and Sirén, V. (1996) Proteinases in subretinal fluid. Graefes Archive for Clinical and Experimental Ophthalmology, 234, 105-109. doi:10.1007/BF00695249

[36] O'Reilly, M. (1997) Angiostatin: An endogenous inhibitor of angiogenesis and of tumor growth. EXS, 79, 273-294.

[37] Geiger, J. and Cnudde, S. (2004) What the structure of angiostatin may tell us about its mechanism of action. Thromb Haemost, 2, 23-34. doi:10.1111/j.1538-7836.2004.00544.x

[38] Chen, Y., Wu, H., Li, C., Huang, Y., Chiang, C., Wu, M. and $\mathrm{Wu}, \mathrm{L}$. (2006) Anti-angiogenesis mediated by angiostatin K1-3, K1-4 and K1-4.5. Involvement of p53, FasL, AKT and mRNA deregulation. Thromb Haemost, 95, 668-677.

[39] Wang, H., Doll, J., Jiang, K., Cundiff, D., Czarnecki, J., Wilson, M., Ridge, K. and Soff, G. (2006) Differential binding of plasminogen, plasmin, and angiostatin 4.5 to cell surface beta-actin: Implications for cancer-mediated angiogenesis. Cancer Research, 66, 7211-7215. doi:10.1158/0008-5472.CAN-05-4331

[40] Kastrikina, T., Taran, L. and Kudinov, S. (1986) Kinetic characteristics of fibrinogen and fibrin hydrolysis by plasmin 1 and 2 and miniplasmin. Thromb Research, 41, 681-688. doi:10.1016/0049-3848(86)90365-8

[41] Kolev, K., Komorowicz, E., Owen, W. and Machovich, R. (1996) Quantitative comparison of fibrin degradation with plasmin, miniplasmin, neurophil leukocyte elastase and cathepsin G. Thromb Haemost, 75, 140-146.

[42] Kolev, K., Léránt, I., Tenekejiev, K. and Machovich, R. (1994) Regulation of fibrinolytic activity of neutrophil leukocyte elastase, plasmin, and miniplasmin by plasma protease inhibitors. Journal of Biological Chemistry, 269, 17030-17034.

[43] Ponting, C., Marshall, J. and Cederholm-Williams, S. (1992) Plasminogen: A structural review. Blood Coagulation \& Fibrinolysis, 3, 605-614. 